\title{
Pengaruh Independensi, Komitmen Organisasi, Struktur Audit Dan Motivasi Kerja Terhadap Kinerja Auditor (Studi Empisis Pada KAP di Kota Malang)
}

\author{
Yuliana Eva ${ }^{1}$, Retno Wulandari' ${ }^{2}$, Mochamad Fariz Irianto ${ }^{3}$ \\ 1,2,3 Program Studi Akuntansi, Fakultas Ekonomika Dan Bisnis, \\ Universitas PGRI Kanjuruhan Malang, Indonesia
}

Corresponding Author

Nama Penulis : Yuliana Eva

E-mail : yulianaeva738@gmail.com

\begin{abstract}
Abstrak
Penelitian ini memiliki tujuan untuk menguji mengenai pengaruh Independensi, Komitmen Organisasi, Struktur Audit dan Motivasi terhadap kinerja auditor di KAP Kota Malang. Metode penelitian yang digunakan adalah metode kuantitatif dengan analisis regresi dengan menggunakan SPSS. Populasi penelitian berjumlah 120 auditor KAP. Teknik pengambilan sampel menggunakan purposive sampling sehingga diperolehjumlah sampel 80 auditor KAP di Kota Malang. Teknik Analisis data dalam peneitian ini yakni melalui uji keabsahan instrumen penelitiian yakni uji validitas dan reliabilitas, Uji asumsi klasik dan analisis regresi linear berganda, uji $t$ dan uji F. Hasil penelitian ini menunjukan bahwa independensi berpengaruh positif signifikan terhadap kinerja auditor di KAP Kota Malang. Variabel komitmen organisasi berpengaruh positif signifikan terhadap kinerja auditor di KAP Kota Malang. Variabel struktur audit berpengaruh positif signifikan terhadap kinerja auditor di KAP Kota Malang. Variabel motivasi kerja berpengaruh positif signifikan terhadap kinerja auditor di KAP Kota Malang. Secara simultan variabelindependensi, komitmen organisasi, struktur audit dan Motivasi kerja berpengaruh positif signifikan terhadap kinerja auditor di KAP Kota Malang.
\end{abstract}

Kata kunci : Kinerja Auditor, Independensi, Komitmen Organisasi, Struktur Audit dan Motivasi kerja

\begin{abstract}
This research is about the influence of Independence, Organizational Commitment, Audit Structure and Motivation on the performance of auditors at KAP Malang City. The research population is 120 KAP employees. The sampling technique used purposive sampling in order to obtain a total sample of 80 people KAP Malang. Data analysis techniques in this research are through testing the validity of research instruments, namely validity and reliability tests, classical assumption tests and multiple linear regression analysis, $t$ tests and $F$ tests. The results of this study indicate that independence has a significant effect on auditor performanceat KAP Malang City. Organizational Commitment variable has a significant effect on the performance of auditors at KAP Malang City. The audit structure variable has a significant effect on the performance of auditors at KAP Malang City. Motivation variable has a significant effect on the performance of auditors at KAP Malang City. Simultaneously the variables of Independence, Organizational Commitment, Audit Structure and Motivation have a significant effect on the performance of auditors at KAP Malang City
\end{abstract}

Keywords : Auditor Performance, Independence, Organizational Commitment, Audit Structure and Motivatio. 


\section{PENDAHULUAN}

Karier akuntan merupakan pekerjaan penting dalam hal penyediaan informasi-informasi keuangan yang sangat berguna bagi pemerintah, investor, debitur, kreditor, dan masyarakat (Sagung Dea, 2014), maka dari itu saat ini profesi akuntan banyak disediakan oleh perusahaan. Kantor akuntan publik adalah suatu organisasiberisikan akuntan publik yang telah memiliki landasan hukum dan telah sesuai dengan perundang-undangan dan bergerak pada bidang jasa praktik akuntan public yang profesional (Kumalaningtyas, 2013). Peran auditor adalah sebagai mediator guna menjalankan perannya sebagai akuntan, auditor. Sebagai penunjang sikap profesionalisme dalam pekerjaan mereka, auditor dituntut untuk berpedoman pada standar audit, antara lain standar umum, standar perkerja lapangan, dan standar pelaporan dengan tetap mempertahankan transparansi, profesionalitas dan independensi kerja, serta mengacu prinsip Good Governance agar tercapainya kinerja auditor yang berkualitas (Firnanti, 2013).

Auditor perlu memiliki sikap independensi yang baik sehingga masyarakat senantiasa memiliki kesan yang baik terhadap mereka. Hal ini disebabkan karena tugas akuntan sangat rentan dipengaruhi oleh kepentingan yang beragam dari klien mereka ataupun masyarakat (Sukma 2014), (Arifah, 2012). Komitmen organisasi sebagai suatu kekuatan individu untuk bertanggung jawab pada pekerjaanya dan juga bertanggung jawab dalam menyelesaikan permasalahan kliennya, salah satu faktor individual yang mempengaruhi peningkatan kinerja adalah komitmen organisasi (Sanjiwani, 2016). Struktur audit membantu auditor dalam melakukan audit lebih menjadi terarah, sehingga dapat meningkatkan kinerja auditor. Selain itu untuk tercapainya kinerja yang baik seorang auditor perlu untuk mempunyai motivasi tinggi sebagai pencapaian tujuan organisasi dan demi tujuan audit yang baik. Auditor yang memiliki motivasi yang kuat dalam dirinya tidak akan dipengaruhi oleh tekanan ketaatan dari atasan maupun entitas yang diperiksa (Fanani, 2018).

Fenomena yang terjadi pada Kantor Akuntan Publik (AP) tahun ini dapat dikatakan tahun yang kurang baik. Hal ini disebabkan adanya temuan kasus yang melanggar etika oleh KAP. Menurut CNBC Indonesia, terdapat $3 \mathrm{KAP}$ yang sangat dikenal masyarakat terlibat dalam kasus ini. Dua dari tiga KAP tersebut bahkan telah terbukti melakukan pelanggaran hukum yang berlaku, KAP tersebut yakni KAP Purwanto, Sungkoro dan Surja yang terbukti telah melakukan pelanggaran UndangUndang Pasar Modal dan kode etik akuntan publik yang mereka lakukan pada kasus pendapatan laporan keuangan pada PT. Hanson International Tbk. dalam periode tahun 2016. Sanksi yang mereka dapatkan atas kasus tersebut yakni pembekuan usaha selama 1 tahun. Sanksi serupa diberikan pula kepada AP Kasner Sirumpea dan KAP Tanubrata, Sutanto, Bambang, Fahmi \& Rekan atas kasus laporan keuangan yaitu penyalahgunaan penyediaan layanan konektivitas PT. Garuda Indonesia Tbk. pada periode tahun 2018 .

Penelitian mengenai pengaruh independensi, komitmen organisasi, struktur audit terhadap kinerja auditor telah dilakukan oleh banyak peneliti diantaranya (Arifah, 2012) (Awaluddin 2017) menunjukan independensi berpengaruh positif dan signifikan terhadap kinerja auditor. Penelitian (Alfianto, dkk., 2015) komitmen organisasi berpengaruh positif terhadap kinerja auditor,namun tidak sejalan dengan penelitian (Erma, 2015) yang menyatakan bahwa komitmen organisasi tidak berpengaruh terhadap kinerja auditor. Penelitian mengenai struktur audit oleh Fanani (2018), menunjukkan bahwa struktur audit berpengaruh positif signifikan terhadap kinerja auditor, namun 
tidak konsisten dengan penelitian (Suryana, 2013) mengunakan model moderasi menunjukan bahwa struktur audit tidak berpengaruh secara langsung terhadap kinerja auditor. Mengenai komitmen organisasi yang dilakukan (Agustini 2013), (Sanjiwani, 2016), komitmen organisasi berpengaruh positif signifikan terhadap kinerja auditor, namun tidak konsisten dengan (Arifah, 2012), (Firnanti, 2013), (Alfianto, dkk., 2015) yakni adanya tidak ada pengaruh yang signifikan atas kontribusi komitmen organisasi.

\section{TINJAUAN PUSTAKA}

\section{a. Kinerja Auditor}

Menurut (Maturidi 2016) menjelaskan kinerja auditor merupakan ungkapan suatu pencapaian kerja auditor didasarkan pada perilaku kerja yang baik dalam melaksanakan tugas merekea demi hasil yang optimal, kinerja tersebut diukur menggunakan dimensi faktor subyektif, yaitu inisiatif, loyalitas dan kerjasama serta faktor obyektif meliputi hasil kerja. Auditor memiliki tugas melakukan pemerikasaan dengan sikap obyektif terhadap laporan keuangan perusahaan untuk melihat apakah laporan keuangan tersebut telah disusun secara benar dan wajar berdasarkan prinsip akuntansi pada seluruh sisi baik secara material, hasil usaha dari perusahaan dan posisi keuangan saat itu.

\section{b. Independensi}

Sikap independen meruapakan salah satu sikap yang diharapkan dalam diri akuntan publik yang mampu untuk menahan beragam pengaruh yang dapat meruntuhkan perilaku netral dan integritas mereka dalam melaksanakan tugasnya, di lapangan para auditor sering kali menemukan hal-hal yang dapat menghilangkan profesionalisme dan independensi mereka ketika bertugas (Mulyadi, 2014). Naryanto (2016) menerangkan sikap independen dengan adanya sikap jujur dalam diri auditor dan memilih untuk tidak memihak serta berpandangan obyektif dalam merumuskan pendapat mereka.

\section{c. Komitmen Organisasi}

(Griffin, 2015) memberikan penjelasan komitmen organisasi merupakan sikap yang mencerminkan individu dapat mengenali dan merasa terikat dengan tempat dimana mereka bekerja. (Kinicki, 2017) menjelaskan komitmen organisasi merupakan kesepakatan yang dibentuk oleh individu bersama dengan organisasi.

\section{d. Struktur Audit}

Sukrisno (2012) memberikan penjelasan mengenai struktur audit yang diartikan sebagai pendekatan sistematis pada proses auditing yang dikarakteristikan dengan cara-cara penentuan audit, dokumentasi, penggunaan instrumen kebijakan audit yang komprehensif dan terintegrasi, prosedur rangkaian yang logis dan keputusan-keputusan demi tindakan stimulus auditor melakukan audit.

\section{e. Motivasi Kerja}

Menurut (Kreitner, 2012) motivasi merupakan konsep yang sangat penting untuk diterapkan oleh auditor, terutama dalam melaksanakan tugas audit yang ditujukan untuk mencapai tujuan organisasi dan auditing yang baik. 


\section{f. Kerangka Konseptual}

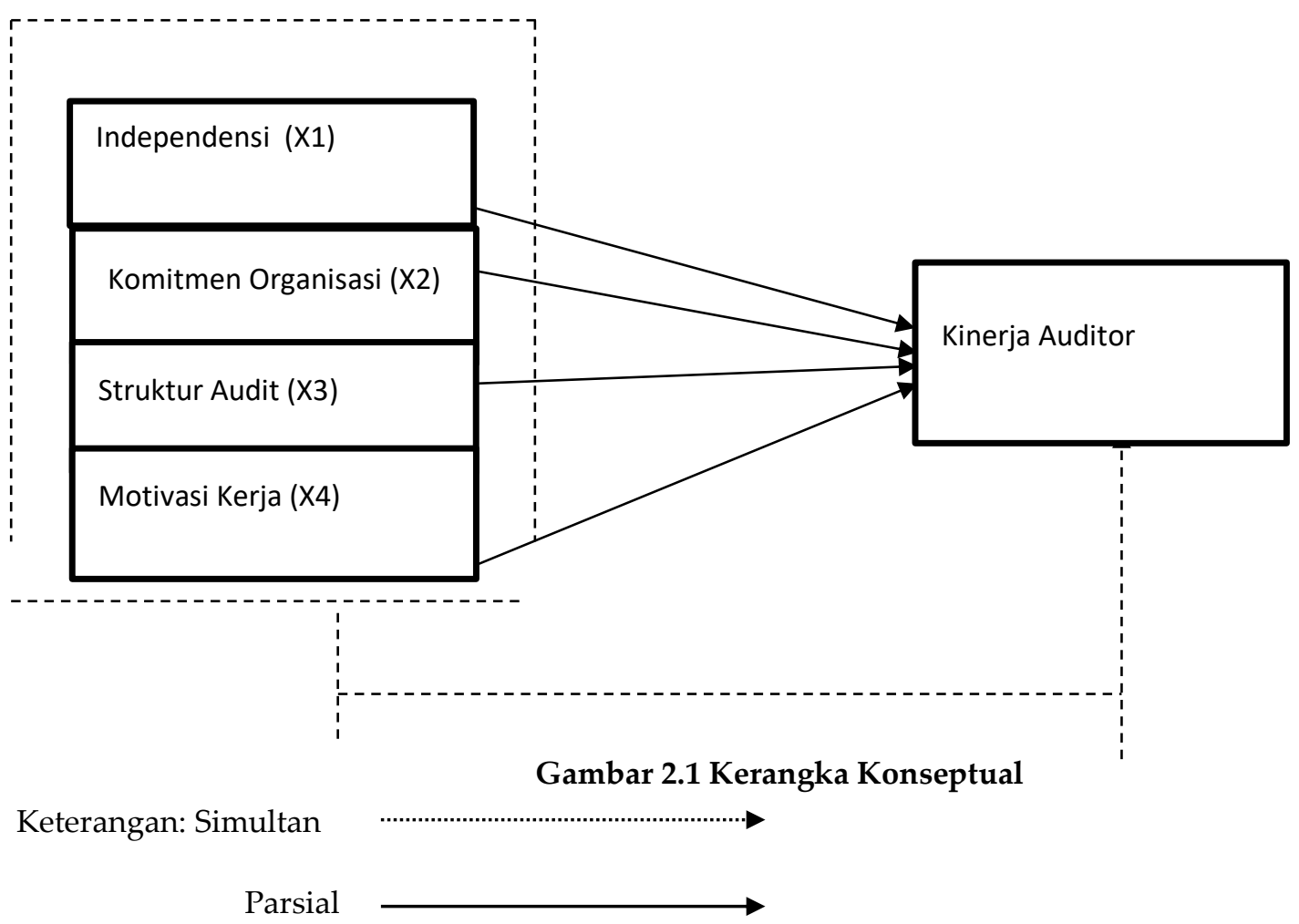

\section{Keterangan hipotesis}

H1: Independensi, Komitmen Organisasi, Struktur Audit dan Motivasi Kerja Berpengaruh Terhadap Kinerja Auditor.

H2: Independensi Berpengaruh Terhadap Kinerja Auditor,

H3: Komitmen Organisasi Berpengaruh Terhadap Kinerja Auditor.

H4: Struktur Audit Berpengaruh Tarhadap Kinerja Auditor.

H5: Motivasi Kerja Berpengaruh Terhadap Kinerja Auditor.

\section{METODE PENELITIAN}

Penelitian yaitu observasi penjelasan yang bertujuan untuk mengartikan hubungan pengaruh antara variabel-variabel penelitian melalui pengujian hipotesis (Faisal, 2012). Metode yang digunakan dari penelitian ini yaitu metode deskriptif kuantitatif merupakan penelitian yang diolah dan dianalisis untuk diambil kesimpulan. Jenis penelitian yang digunakan yaitu survei, dimana survei yang dipilih ialah kuesioner yang akan dibagikan kepada objek penelitian, objek dari penelitian adalah auditor yang bekerja pada KAP di Kota Malang. Metode penelitian ini menggunakan pendekatan deskriptif kuantitatif yakni melakukan pengujian kausal yaitu pengujian sebab akibat terhadap variable dependen yang disebabkan oleh pengaruh variable independen. Populasi penelitian ini adalah 120 
orang yakni empat kriteria yaitu senior auditor, supervisor, manajer, partner di KAP Kota Malang. Penentuan sampel menggunakan purposive sampling yakni dengan menggunakan pertimbangan tertentu. Dengan demikian jumlah sampel pada penelitian ini sesuai ketentuan penelitiadalah 87 sampel. Teknik analisis data menggunakan uji validitas dan reliabilitas, uji asumsi klasik dan analisis regresi linear berganda serta uji hipotesis.

\section{HASIL DAN PEMBAHASAN}

\section{A. Hasil}

Dilakukannya analisis deskriptif untuk menjelaskan angka yang di peroleh. Adapun hasil dari penelitian dan analisis deskriptifnya yaitu, pada variabe $Y$ yaitu kinerja auditor dengan jumlah data 80 responden memiliki nilai rata-rata sebesar $31,60 \%$.

Pada variabel X1 yaitu independensi adapun hasil dari variabel independensi dengan jumlah data responden 80 orang dan memiliki total nilai rata-rata untuk variabel independensi adalah $34,31 \%$.

Pada variabel X2 yaitu komitmen organisasi adapun hasil dari variabel komitmen organisasi dengan jumlah data responden 80 orang dan memiliki total nilai rata-rata untuk variabel komitmen organisis adalah $22,70 \%$

Pada variabel X3 yaitu struktur audit adapun hasil dari variavel struktur audit dengan jumlah data responden 80 orang dan memiliki total nilai rata-rata untuk variabel struktur audit adalah $23,91 \%$

Pada variabel $\mathrm{X} 4$ yaitu motivasi kerja adapun hasil dari variabel motivasi kerja dengan jumlah data responden 80 orang dan memiliki total nilai rata-rata untuk variabel motivasi kerja adalah $23,48 \%$

\section{Analisis Regresi Linear Berganda}

Analisis regresi berganda berguna untuk melihat besarnya pengaruh independensi, komitmen organisasi, struktur audit dan motivasi kerja terhadap kinerja auditor.

Hasil analisis regresi linear berganda

\begin{tabular}{|c|c|c|c|c|c|c|c|}
\hline \multirow[b]{2}{*}{ Model } & \multicolumn{2}{|c|}{$\begin{array}{l}\text { Unstandardized } \\
\text { Coefficients }\end{array}$} & \multirow{2}{*}{$\begin{array}{c}\text { Standardize } \\
\text { d } \\
\text { Coefficients }\end{array}$} & \multirow[b]{2}{*}{$\mathrm{t}$} & \multirow[b]{2}{*}{ Sig. } & \multicolumn{2}{|c|}{$\begin{array}{l}\text { Collinearity } \\
\text { Statistics }\end{array}$} \\
\hline & B & $\begin{array}{l}\text { Std. } \\
\text { Error }\end{array}$ & & & & $\begin{array}{c}\text { Toleranc } \\
\text { e }\end{array}$ & VIF \\
\hline (Constant) & 4,865 & 7,187 & & 677 &, 501 & & \\
\hline Independensi_X1 & 472 & 116 & 423 & 4,083 & 000 & ,919 & 1,088 \\
\hline $\begin{array}{l}\text { Komitmen_Organisasi_X } \\
2\end{array}$ & 403 & 140 & 296 & 2,877 & ,005 & ,928 & 1,078 \\
\hline Struktur_Audit_X3 &,- 376 & 131 &,- 303 & $-2,868$ & ,005 & ,885 & 1,130 \\
\hline Motivasi_Kerja_X4 & ,424 & 211 & 204 & 2,013 & 048 & 961 & 1,041 \\
\hline
\end{tabular}

a. Dependent Variable: Kinerja_Auditor_Y

Sumber : Data diolah 2021.

Menunjukan model persamaan regresi yang dihasilkan adalah sebagai

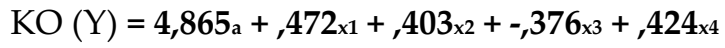

Model persamaan regresi dapat dijelaskan sebagai berikut; 
1) Nilai Constant sebesar 4,865 yang memiliki arti bahwa jika tidak ada variable independensi $(x 1)$, variabel komitmen organisasi (X2), struktur audit (X3) dan motivasikerja (X4), maka kinerja auditor (Y) sebesar 4,865 atau sangat tinggi.

2) Nilai Coefisient independensi (X1) sebesar, 472 menunjukan bahwa $X 1$ memiliki pengaruh positif (searah) terhadap Y, yang artinya jika variabel independensi (X1) ditingkatkan kenaikkannya satu kali, maka variabel kinerja auditor (Y) akan mengalami peningkatan sebesar ,472 dan sebalik nya.

3) Nilai Coefisient komitmen organisasi ( $X 2$ ) sebesar, 403 menunjukan bahwa $X 2$ memiliki pengaruh positif (searah) terhadap Y, yang artinya jika variabel komitmen organisasi (X2) ditingkatkan kenaikkannya satu kali, maka variabel kinerja auditor (Y) akan mengalami peningkatan sebesar ,403 dan sebalik nya.

4) Nilai Coefisient strukrur audit $(X 3)$ sebesar -,376 menunjukan bahwa $X 3$ memiliki pengaruh positif (searah) terhadap Y, yang artinya jika variabel struktur audit (X3) ditingkatkan kenaikkannya satu kali, maka variabel kinerja auditor (Y) akan mengalami peningkatan sebesar -,376 dan sebalik nya.

5) Nilai Coefisient motivasi kerja(X4) sebesar, 424 menunjukan bahwa $X 4$ memiliki pengaruh positif (searah) terhadap Y, yang artinya jika variabel motivasi kerja (X4) ditingkatkan kenaikkannya satu kali, maka variabel kinerja auditor (Y) akan mengalami peningkatan sebesar ,424 dan sebalik nya.

\section{B. PEMBAHASAN}

Berdasarkan analisis regresi secara parsial yang telah dilakukan, variabel independensi, komitmen organisasi, struktur audit dan motivasi kerja memengaruhi kinerja auditor. Kinerja auditor yang sangat penting ini perlu untuk dikomparasikan dengan standar yang ditandai dengan penyelesaian tugas dengan menggunakan seluruh keterampilan dan pengetahuan yang dimiliki, tugas yang dapat diselesaikan sesuai dengan target serta kemampuan auditor dalam memaksimalkan penggunaan resources yang tersedia untuk menyelesaikan tugas yang kompleks dan terstruktur.

Secara parsial, variabel independensi memiliki pengaruh yang positif dan signifikan terhadap kinerja auditor. Jika auditor sungguh-sungguh memiliki sikap independen, maka mereka tidak akan terjerumus dalam pengaruh kliennya dan auditor akan dengan mudah dan bebas dalam melaksanakan tugasnya. Namun, jika para auditor kehilangan independensi mereka saat bertugas akibat tekanan dari klien mereka, maka kualitas dari hasil audit mereka akan condong tidak maksimal dan tidak menggambarkan keadaan yang sebenarnya dalam perusahaan. Hal tersebut berdampak pada "wrong decision" atau ketidaktepatan pengambilan keputusan. Independensi pada penelitian ini menunjukkan kebebasan posisi auditor yang bekerja di KAP Kota Malang baik sikap maupun penampilan dalam hubungannya dengan klien yang terkait dengan tugas audit yang dilaksanakan.

Secara parsial, variabel komitmen organisasi memiliki pengaruh yang positif dan signifikan terhadap kinerja auditor. Komitmen organisasi sebagai kekuatan yang bersifat relatif dari individu dalam mengidentifikasi keterlibatan dirinya dalam organisasi.

\section{Pengaruh struktur audit terhadap kinerja auditor}

Secara parsial, variabel struktur audit berpengaruh positif signifikan terhadap kinerja auditor. Dengan adanya struktur audit, auditor akan lebih mudah dan terarah dalam melakukan audit sehingga akan mempengaruhi kinerja mereka yang akan semakin meningkat. Sebaliknya, bila staf audit tidak 
memahami secara detail mengenai struktur audit, maka akan berdampak pada kesulitan mereka dalam bertugas disebabkan karena ketidakpahaman mengenai koordinasi arus kerja, komunikasi, wewenang yang dimiliki serta kemampuan beradaptasi.

Secara parsial, variabel motivasi kerja berpengaruh secara positif signifikan terhadap kinerja auditor, karena seorang auditor perlu untuk memiliki motivasi yang tinggi demi ketercapaian tujuan organisasi dan hasil audit yang baik. Ciri-ciri auditor yang memiliki motivasi tinggi yaitu mereka tidak akan terpengaruh tekanan-tekanan yang diberikan dari atasan ataupun entitas yang sedang diperiksa. Seorang auditor yang bermotivasi tinggi pula akan berusaha untuk mengasah kemampuan dan pengetahuan mereka dengan sarana pendidikan formal maupun pelatihan sertifikasi.

\section{KESIMPULAN DAN SARAN}

\section{A. KESIMPULAN}

Berdasarkan hasil penelitian dan pengolahan data yang telah dilakukan terkait Independensi, Komitmen Organisasi, Struktur Audit, Motivasi Kerja Terhadap Kinerja Auditor Pada Kantor Akuntan Publik Kota Malang dan olah data menggunakan aplikasi SPSS versi 21 maka dapat disimpulkan bahwa secara parsial dan simultan masing-masing variabel independen berpengaruh signifikan terhadap kinerja auditor di KAP Kota Malang.

Variabel independensi, komitmen organisasi, struktur audit dan motivasi kerja berpengaruh secara simultan terhadap kinerja auditor. Hasil ini menunjukkan bahwa semakin baik independensi, komitmen organisasi, struktur audit dan motivasi kerja maka kinerja auditor yang dihasilkan semakin berkualitas.

Variabel independensi berpengaruh positif signifikan terhadap kinerja auditor. Hasil ini menunjukkan bahwa dalam sebuah kantor akuntan publik yang memiliki auditor yang independensi maka akan semakin baik pula kantor akuntan publik tersebut.

Variabel komitmen organisasi berpengaruh positif signifikan terhadap kinerja auditor. Hasil ini menunjukkan auditor yang berkomitmen terhadap organisasi akan menunjukkan sikap dan perilaku yang positif terhadap lembaganya, auditor akan memiliki jiwa tetap membela organisasinya, berusaha meningkatkan prestasi, dan memiliki keyakinan yang pasti untuk membantu mewujudkan tujuan organisasi.

Variabel struktur audit berpengaruh positif signifikan terhadap kinerja auditor. Hasil ini menunjukan penggunaan struktur audit dapat membantu auditor dalam melaksanakan tugasnya menjadi lebih baik sehingga dapat meningkatkan kinerja auditor

Variabel motivasi kerja berpengaruh positif signifikan terhadap kinerja auditor. Hasil ini menunjukkan motivasi kerja yang baik pada auditor menimbulkan semangat ataupun dorongan berkerja pada auditor terhadap perkerjaannya untuk mencapai tujuan. Apabila dorongan seseorang berkerja tinggi maka kinerja yang dicapai akan tinggi pula.

\section{B. SARAN}

Sesuai hasil dipenelitian yang sudah dilakukan, maka dapat disampaikan saran-saran pada pihak tertentu yang memerlukan, yaitu yang pertama bagi pihak kantor KAP Tingkat kompetensi yang semakin ketat oleh karena itu kantor akuntan publik perlu meningkatkan independensi auditor untuk membangun fundamental kantor yang kokoh serta berkelanjutan, besar kecilnya ukuran kantor 
haruslah di imbangi dengan kemampuan kantor dalam mengelola aset dan modal serta kepercayaan klien yang dimiliki kantor akuntan publik sehingga dapat menjadikan nilai kantor akuntan publik semakin meningkat lebih baik.

Bagi klien Klien haruslah lebih bijak dalam memutuskan menggunakan jasa audit di suatu kantor akuntan publik. Klien sebaiknya mempertimbangkan berbagai aspek ketika menggunakan jasa audit klien haruslah lebih teliti melihat tingkat nilai kantor akuntan publik yang diinginkan dengan mempertimbangkan segala resikonya dan lebih memperhatikan apakah auditor dari kantor tersebut memilliki independensi, komitmen organisasi, struktur audit dan motivasi kerja.

Bagi peneliti selanjutnya Sebaiknya peneliti selanjutnya melakukan penelitian serupa namun dengan sektor yang berbeda dan dengan jumlaha spek yang lebih banyak sehingga mampu memperkuat hasil penelitian yang telah dilakukan, menambahkan variabel lain yang relevan terkait dengan kinerja auditor seperti etika profesi karena etika profesi sangatlah dibutuhkan oleh masingmasing profesi, untuk mendapatkan kepercayaan dari masyarakat, setiap auditor harus mematuhi etika profesi mereka agar tidak menyimpang dari aturan dalam menyelesaikan laporan keuangan klien. Kode etik yang dipahami dan dijalankan oleh seorang auditor tentunya akan mempengaruhi kinerja auditor.

\section{Daftar Pustaka}

Arikunto. (2016). Pengaruh Konflik Peran, Ketidakjelasan Peran, Struktur Audit, Motivasi Dan Kepuasan Kerja Pada Kinerja Auditor. E-Jurnal Akuntansi Universitas Udayana (UNUD)12.1, 1, 249-264.

Atawarman. (2011). The Effect of Organizational Culture, Leadership Style, and Functional Position on Organizational Commitment and Their Impact on The Performance of Internal Auditors in Aceh , Indonesia. BRAND. Broad Research in Accounting, Negotiation, and Distribution, 7(1), 37-50. https://doi.org/2067-8177

Bhagat. (2017). Pengaruh Independensi Auditor, Pemahaman Good Governance dan Self Efficacy Terhadap Kinerja Auditor Pada KAP Bali. E-Jurnal Akuntansi, 27, 1839. https://doi.org/10.24843/eja.2019.v27.i03.p08

Budiman, S. P. (2017). Pengaruh Struktur Audit, Locus Of Control, dan Komitmen Organisasi terhadap Kinerja Auditor Pemerintah (Studi Empiris pada Auditor pemerintah di Inspektorat Kab.Agam, Kota Padang dan Kota Padang Panjang). Artikel Skripsi.

Erma. (2015). Pengaruh Profesionalisme, Budaya Organisasi dan Komitmen Organisasi pada Kinerja Auditor.E-Jurnal Akuntansi, 22, 1059. https:// doi.org/10. 24843/eja.2018. v22.i02. p09

Faisal. (2012). Pengaruh Stres Kerja terhadap Motivasi dan Kinerja Auditor pada Kantor Akuntan Publik di Kota Medan. Akuntansi, XVII(1), 75-83.

Golleman. (2011). Analisis Pengaruh Kepemimpinan, Motivasi, Disiplin Kerja Dan Lingkungan Kerja Terhadap Kinerja Karyawan Taman Botani Sukorambi ( Tbs ) Jember. Goleman, 3(1), 1-17. http://jurnal.unmuhjember.ac.id/index.php/JMBI/article/view/780/619

Ghozali. 2011. “E-Jurnal Akuntansi Universitas Udayana Pengaruh Locus of Control Internal , Motivasi Kerja, Gaya Kepemimpinan Transformasional , Komitmen Made Mas Sendhi Rahayu 1 Fakultas Ekonomi Dan Bisnis Universitas Udayana ( Unud ), Bali , Indonesia Fakultas Ekon." 19: 2378-2406. 
Hanna dan firnanti tahun2013. (2014). pengaruh konfilik peran, ketidakjelasan peran, struktur audit, motivasi dan kepuasan kerja pada kinerja auditor (study empiris pada auditor yang berkerja di KAP MALANG). Ekonomi, 1-5.

Idris. (2012). Pengaruh Struktur Audit Terhadap Kinerja Auditor Dengan Komitmen Organisasi Sebagai V ariabel Pemoderasi. Jurnal Proaksi Fakultas Ekonomika Dan Bisnis Universitas Stikubank Semarang, Indonesia, 4(1), 1-20.

Mardika, Ida Bagus Angga, and I Wayan Suartana. 2019. “Pengaruh Independensi, Pengalaman Kerja, Komitmen Organisasi, Dan Motivasi Auditor Pada Kualitas Audit.” E-Jurnal Akuntansi 27: 2211.

Martini. (2016). the Professionalism, Competence, Organizational Commitment \& Job Satisfaction on the Performance of Auditor. The International Journal of Business Review (The Jobs Review), 2(2), 87-104. https://doi.org/10.17509/tjr.v2i2.21345

Mutia Fauzia. (2018). OJK Jatuhkan Sanksi terhadap Akuntan Publik dan Auditor SNP Finance. Kompas.Com. https://ekonomi.kompas.com/read/2018/10/01/171444326/ojk- jatuhkan- sanksiterhadap-akuntan-publik-dan-auditor-snp-finance 